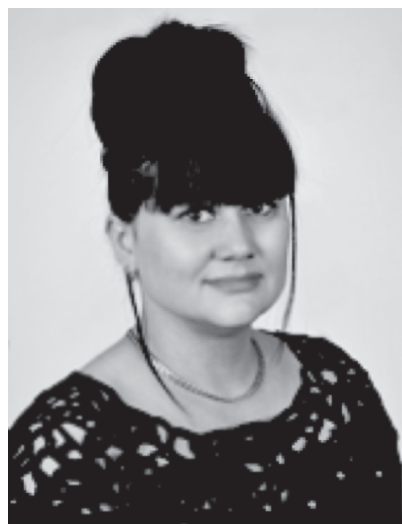

Natalija Litovčenko - filologijos mokslų daktarè, Chersono valstybinio universiteto (Ukraina) prof. O. Mišukovo vardo Pasaulinès literatūros ir kultūros katedros lektorè. Moksliniai interesai: rusų literatūra, pasaulio literatūra, kultūra ir istorija, literatūros teorija.

Adresas: Chersono 200-ečių pr. 35-19, 73039, Chersonas, Ukraina.

El. paštas: Skarlett75@mail.ru.

Nataliia Lytovchenko: candidate of Philological Sciences (PhD), Kherson State University, Prof. O. Mishukov World Literature and Culture Chair; lecturer.

Field of interests: Russian literature, world culture, world history, literary theory.

Address: 200 rokiv of Kherson, 35, 19, 73039 Kherson, Ukraine. Phone: +380991427784 .

E-mail: Skarlett75@mail.ru.

\title{
Наталия Литовченко
}

Херсонский государственньй университет

\section{КОНЦЕПТ «ДУХОВНОГО СТРАННИЧЕСТВА» В ЛИРИКЕ АНДРЕЯ БЕЛОГО И ЮРГИСА Б АЛ Т РУШАЙТ ИСА : ТИПОЛОГИЧЕСКИЙ А СПЕК Т}

\begin{abstract}
Anotacija
Šio tyrimo objektas yra „dvasiniu klajonių“ koncepto meninė išraiška XX a. pradžios poezijoje. Straipsnyje analizuojamos „dvasiniu klajonių“ transformacijos Andrejaus Belyj (Андрей Бельıй) ir Jurgio Baltrušaičio kūryboje. Remiantis idejjinio-teminio „dvasinių klajonių“ branduolio samprata, išskiriami ir analizuojami tipologiniai panašumai bei skirtumai, susiformavę religinèje-poetinèje kūrèjų sąmonèje.

PAGRINIDINIAI ŽODŽIAI: ,dvasinès klajonès“, konceptas, motyvas, mitologema, religinè-poetinè sąmonè.
\end{abstract}

\section{Аннотация}

Предметом исследования является художественное воплощение концепта «духовное странничество» в культурной памяти поэзии начала XX века. В статье представлены трансформации «духовного странничества» в творчестве А. Белого и Ю. Балтрушайтиса. Исходя из идейно-тематического «ядра» понятия «духовное странничество», выявлены типологические схождения, проанализированы отличия, связанные с религиозно-поэтическим сознанием поэтов и их авторским мифотворчеством.

КЛЮЧЕВЫЕ СЛОВА: «духовное странничество, концепт, мотив, мифологема, религиозно-поэтическое сознание. 
DOI: http://dx.doi.org/10.15181/rh.v19i0.1356

В рамках статьи, целью которой является изучение феномена «духовного странничества» в творчестве Юргиса Балтрушайтиса и Андрея Белого, представляется необходимым определить содержание номинации "духовный странник» и установить его место и роль в религиозно-поэтическом сознании двух выдающихся представителей символизма.

Архетипический образ странничества изучается с различных точек зрения. Культурологический аспект странничества отмечают такие мыслители, как Э. Блох, Л. Гумилев, Ю. Лотман, М. Мамардашвили, Б. Успенский, П. Флоренский. Странничество в мифологическом контексте рассматривают Л. Невская, В. Пропп, В. Топоров, Т. Цивьян и др. Национальное понимание и восприятие странника исследуют Г. Гачев, Д. Лихачев, Ю. Степанов, И. Моклецова, Н. Лау и др. Н. Бердяев склонность к «духовному странничеству» относит к «парадоксальности русской души» (Бердяев 1997, 208), у В. Ключевского «русского странника создает степь» (Ключевский 1938, 206). Путь, как обязательное условие странничества рассматривают М. Бахтин и Ю. Лотман. М. Бахтин видит путь «как категорию хронотопа» (Бахтин 1975, 234), у Ю. Лотмана «путь - это непрерывная последовательность состояний» (Лотман 1992, 413).

В литературоведении XXI века ученые приходят к общему пониманию концепта «духовное странничество» как внутреннему движению человека на пути к Богу, «это внутренняя и внешняя жизнь человека, равнодушного к земному и живущему только духом. В этом мире такой человек есть странник, то есть сторонний всего того, что привязывает его к суетному миру» (Лау 2007, 293).

И. Моклецовой выделены три пути «духовного странничества». Первый путь - путь богоискателей, которые жаждут, но не могут найти Христа (Моклецова 2014, 132). Второй путь - путь «ухода от ограды Христовой», путь желания создать собственную религию (Моклецова 2014, 132). Третий путь - «светлый путь странничества, когда, порвав с уютом и семьей, выходят странники во имя Христа на дорогу для того, чтобы уйти с нее в могилу» (Моклецова 2014, 132). 
Наталия Литовченко

Концепт «духовного странничества» в лирике Андрея Белого

и Юргиса Балтрушайтиса: типологический аспект

Данная типология используется нами при описании характеристики концепта «духовное странничество» в религиозно-поэтическом сознании Андрея Белого и Юргиса Балтрушайтиса. По мнению ученых, концепт «духовного странничества» в лирике поэтов-символистов необходимо рассматривать сквозь призму религиозных исканий православного человека.

Наша задача - обратить внимание и на ту черту национальной ментальности, которая названа Н. Бердяевым «духовным странничеством» и определить, как представляется концепт «духовного странничества» в религиозно-поэтическом сознании А. Белого и Ю. Балтрушайтиса, если А. Белый, по мнению М. Дунаева, «православия ... не знал и не хотел знать» (Дунаев 2001-2003, 292), а национальные корни Ю. Балтрушайтиса тесно связаны с католицизмом. На наш взгляд, в религиозно-поэтическом сознании А. Белого и Ю. Балтрушайтиса мотив «духовного странничества» обрастает «вариациями на тему».

В системе религиозно-философских мотивов поэзии А. Белого и Ю. Балтрушайтиса инвариантный мотив «духовного странничества» является доминантным. В нем отражены мистические и теургические интенции поэтов-символистов, связанные:

- с поиском «Нового неба и Новой земли» (Нового Иерусалима);

- с надеждой на встречу с Христом или Абсолютом;

- с провозглашением собственной религии, заключающую в себе надежду на преображение мира и человека.

В поэзии А. Белого и Ю. Балтрушайтиса лирический герой, мыслящий категориями теургии, преодолевает духовный путь и решает, с точки зрения поэтов, основную жизненную и религиозную задачу: преображает и раскрывает мир в себе и вокруг себя, создает единое пространство. Для реализации своих теургических религиозно-философских идей поэты-символисты используют мифологию, так как она, с одной стороны, «способствует преобразованию мира», с другой - миф становится как бы связующим звеном между поэтом и народом. По А. Белому, любое произведение искусства является мифом, поскольку наделено религиозным смыслом. По мнению литературоведов (А. Лавров, А. Пайман, Л. Силард, Л. Колобаева, В. Бычков), поэты, заимствуя традиционные мифологические сюжеты, творят авторский миф. И действительно, в работах А. Белого теургия 
определена как «богоделание», «мифотворчество» и выглядит следующим образом: «Слово рождало образный символ - метафору; метафора представлялась действительно существующей; слово рождало миф; миф рождал религию...» (Белый 1994, 237). Эти тенденции нашли свое воплощение в лирике А. Белого в авторском мифе об «аргонавтах», которые отправляются в путь, а если быть более точным - опасное путешествие, только не за золотым руном, как в древнегреческом мифе, а за весенним солнцем, пьянящей радостью, за «раем на земле».

«Инверсионная» проекция мотива «духовного странничества» представлена в цикле А. Белого «Жизнь». Цикл посвящен Ю. Балтрушайтису, который вместе с Эллисом, Сергеем Соловьевым и А. Белым посещал кружок «Братство аргонавтов». Поэтов символистов А. Белого и Ю. Балтрушайтиса никогда не связывали узы дружбы, да и их творческие миры, можно противопоставить как мир «дионисийский» и мир «аполлонический», так как по мнению А. Лаврова «с безмерностью и динамизмом творческих осуществлений А. Белого контрастирует размеренная гармония лирики Балтрушайтиса» (Лавров 2007, 214). Несмотря на то, что глубоких личных отношений между А. Белым и Ю. Балтрушайтисом не было, цикл стихотворений написан под впечатлением этих встреч. Поэт использует характерные для творчества Ю. Балтрушайтиса скандинавские пейзажи и «нордические» мотивы. Мифологизированный образ поэта-литовца аккумулирует в себе красоту сурового и безмолвного Севера (Лавров 2007, 208).

Образно-семантической доминантой является укорененный в мировой литературе мотив уподобления жизни морскому плаванию. Путь моряков-«аргонавтов» на шхуне жизни начинается мистическими «чаяниями» преображения действительности, а завершается сомнениями в правильности выбранного курса. О том, что это аргонавты, свидетельствуют ключевые в поэтике А. Белого тропы, образы, лексемы: «чаши с янтарным вином», «ясный рубин», «душа молодая просила обмана», «крылатая шхуна», метафора «сияя перстами, заря расцветала» - аллюзия на известные гомеровские строки из «Одиссеи»: «Встала из мрака младая с перстами пурпурными Эос».

Уже в первом стихотворении цикла актуализирован мотив «аргонавтического» путешествия, связанный с семантикой корабля как са- 
Наталия Литовченко

Концепт «духовного странничества» в лирике Андрея Белого

и Юргиса Балтрушайтиса: типологический аспект

крального символа. Н. Медведева, исследуя мифологему корабля в поэзии И. Бродского и О. Седаковой, отмечает, что образ корабля (шхуны) трактуется двояко (Медведева 2007, 234). С одной стороны, образ корабля синонимичен образу смерти, с другой - является аллегорией государства (Медведева 2007, 234-238). Ссылаясь на авторитетных ученых (О. Фрейденберг, В. Топорова, Э. Тайлор), Н. Медведева отмечает, что архаическая семантика корабля, плывущего через горизонт, связана с символическим «шествием тотема по небесному и подземному океану» в первобытном мировоззрении, в «примитивной культуре прошлого» (Э. Тайлор), в античной литературе (Вергилий «Энеида»), в поэзии (А. Рембо «Пьяный корабль», Ш. Бодлера «Плаванье», Н. Гумилева «Заблудившийся трамвай», И. Бродского «Рождественский романс), в образности которых воплощена мифологема корабля мертвых (Медведева 2007, 188). Как видим, в близкой семантике реализуется мифологема корабля и у А. Белого, поскольку заключает в себе мотив неосуществленного путешествия, неисполненной мечты-полета: «Крылатая шхуна вдали утопала».

Во втором стихотворении цикла «Года проходили... Угрозой седою» в инвариантном мотиве странствия появляется образ смерти, которая представлена в антропоморфном виде старушки. На образносимволическом уровне образ смерти связан с мотивами одиночества, тоски, бессмысленности пройденного пути, осознания заблуждений и смиренного приятия своей участи. «Приращению» танатологических смыслов служит семантическая цепочка: «белые льды» - «полярные льды», «стена наплывающих льдин» - «полярная ночь» - «холодная заря». «Снежные» ассоциации направляют читателя к циклу «Зима» (сборник «Урна»), к четвертой симфонии А. Белого «Кубок метелей». В мифопоэтике А. Белого мотив вьюги и метели является амбивалентным. Снежная вьюга выступает символом смерти, за которой следует воскресение из мертвых, преображение и спасение (ТилкесЗаусская).

В третьем стихотворении цикла «творческая инерция преображения» (А. Лавров) получает новое развитие. Инвариантный мотив странничества разрешается в сложных переживаниях лирического героя. Его трагические предчувствия «апокалипсического» конца 
наполнены верой в будущее преображение: «Пускай же охватит нас тьмы бесконечность / - сжимается сердце твое? / Не бойся: засветит суровая Вечность / полярное пламя свое!» (Белый 2008, 594). В образе лирического героя запечатлена вера поэта в скорый эсхатологический конец, за которым последует преображение Неба и Земли. Светлый финал стихотворения поддерживается пушкинской реминисценцией: «... правнуки наши / зарю будут песней встречать» (Белый 2008, 594). Таким образом, как показывает текстуальный анализ, инвариантный мотив преображения, вариантом которого является мотив «духовного странничества», тесно связан с доминантным в религиозно-поэтическом сознании А. Белого эсхатологическим мотивом.

С темой пути и проблемой духовных поисков также связан мотив уподобления жизни морскому плаванию в лирике Ю. Балтрушайтиса, ярко заявленный в ряде стихотворений: «На отмели», «На берегу», «Ночные крылья», «Маятник», «Кормчий», но реализованный в несколько иной тональности. В стихотворениях представлен образ моря в двух ракурсах:

- как символ божественного «нового мира»: «Божий мир для нас как море, мы на темном берегу» («На отмели»), «И безбольно, с отрадною грустью, / Трепетанием звезд осиян, / Как река, что отхлынула к устью, / Я вливаюсь в святой океан» («На берегу»). В этих стихотворениях, лирический герой, преодолевая путь между землей и морем, видит мир ирреальный мечты, в котором море становится сакральным местом, воплощением сферы рая. Сакральный образ корабля (парусника) воспринимается как раннехристианский знак Христа и его Церкви;

- как символ смерти в стихотворениях «Кормчий», «Маятник»: «В беге сквозь пену, сквозь брызги, / Взрытые синею тьмой, / Строен в их свисте, в их визге, / Кормчий глухой и немой... / Только в смятении диком / Вскинутых к небу валов / Чудится слитый с их криком, / Хохот проклятья без слов...» («Кормчий»); «Будто с угрюмой мольбой о былом / Сумрачный Кормчий упорным веслом / Глухо, размеренно гонит ладью / Вдаль, в неизвестную пристань мою» («Маятник»). В стихотворении «Маятник» лирический герой чувствует дыхание смерти. 
Наталия Литовченко

Концепт «духовного странничества» в лирике Андрея Белого

и Юргиса Балтрушайтиса: типологический аспект

Он ощущает свое экзистенциальное одиночество на границе двух миров. Он слышит «грузную поступь», представленного в символико-аллегорическом образе Кормчего, ассоциирующегося с Хароном. Смысл стихотворений создается контрапунктом двух тем: жизни и смерти за счет традиционной аллегории корабль-жизнь, корабль-смерть.

Символика стихотворения «Кормчий» также ассоциируется с античным мифом о перевозчике царства мертвых. Субъектно-образная структура стихотворения «Кормчий» моделирует визионерскую ситуацию странничества лирического героя между двумя мирами. Автором разворачивается пространственно-временная модель мира с определенным набором двоичных оппозиций, принадлежащих к парадигме мифопоэтических представлений о кормчем корабля: «В ярости бурь, в океане, / Старец седой у руля / Держит в бестрепетной длани / Жребий и бег корабля...» («Кормчий»). Ю. Балтрушайтис наделяет Кормчего эпитетами «молчаливый Старик», «седой старец», «сумрачный Кормчий», «глухой и немой», семантика которых позволяет сопоставить образ Кормчего с образом смерти. На образно-символическом уровне образ смерти связан с мотивами движения по направлению к загробному миру «Гонит Он трепет Галеры / К берегу мира и сна...» («Кормчий»), скоротечности времени, обреченности «В тягостном сумраке ночи немой / Мерно качается Маятник мой, / С визгом таинственным, ржаво скрипя, / Каждый замедливший миг торопя» («Маятник»), неизбежности смерти «Скорбный и мерный, отрывистый звон - / Шествие Часа в пустыне времен...» («Маятник»). Аллегорический смысл стихотворений «Маятник» и «Кормчий» заключается в изображении жизни как странствия к Вечности.

Как известно, мифологема пути маркирована словами сигналами: «кайма», «рамка», «межа», «указатель» («придорожный камень», «столб», «крест», «веха»), «поворот», «мост», «застава», «круг», «кольцо», «спираль», «синусоида», «стрела», «возврат», «горизонт», «горизонталь / вертикаль», «тупик», «обочина», «поле», «тропа», «гора», «серпантин» и пр. Особое значение имеет вектор пути: «геометрия прямого (правденого) пути, кривизна «бесовского вождения (кружение кривды, блуд, блуждания / демонической распутицы» (Исупов 2002). 
Миф о пути лирического героя Ю. Балтрушайтиса - «часть мифологизированной концепции его творческой эволюции, которая, в свою очередь, часть «глобального» мифа о «пути мира» (Минц). Названия сборников «Земные ступени» и «Горная тропа» определяются инвариантный мотив пути и его вариативный мотив «духовного странничества». Лирический герой отравляется в странствие, ищет спасение, верит в эсхатологическое предопределение, мистически уповая на чудо. В религиозно-поэтическом сознании Ю. Балтрушайтиса земные ступени есть восхождение к вершинам духа «Мы - туманные ступени к светлым высям божьих гор» («Ступени»), именно так реализуется путь лирического героя «к последней высоте». Герой противопоставляет бесцельности человеческого бытия свое собственное пониманием пути как добровольной дани жестоким космическим законам. Что касается горного пути, то образ горы, с одной стороны, синонимичен образу Голгофы - месту казни, распятия Христа и является аллегорией смерти, с другой - местом пребывания божественных сил. В религиозно-поэтическом сознании Ю. Балтрушайтиса странник в сборнике «Горная тропа», преодолев долгий путь восхождения, по мнению Б. Мержвинските «выступает как посредник между земным и небесным мирами, преображает божественное в человеческое и возвышает человеческое на уровень божественного» (Мержвинските 2014, 210).

Литературоведами (А. Пайман, Л. Колобаевой, Н. Ильинской) неоднократно отмечено, что векторы духовных исканий символистов не располагаются исключительно внутри исторического христианства и его церковных стен, поскольку это «новое религиозное сознание». Когда В. Вейдле не без иронии называет его не философской, а литературной идеей (Исупов 2001, 73), то не грешит против истины. Ю. Балтрушайтис как один из ярких представителей символизма также не остался равнодушным к многоаспектным веяниям своего времени. Об этом пишет В. Дауетите, по утверждению которой на религиозно-поэтическое сознание Ю. Балтрушайтиса оказала заметное влияние «пантеистическая торжественность, характерная для теософии» (Дауетите, 145).

В семантическом поле концепта «духовное странничество» Ю. Балтрушайтисом актуализирован характерный для поэзии модернистов 
Наталия Литовченко

Концепт «духовного странничества» в лирике Андрея Белого

и Юргиса Балтрушайтиса: типологический аспект

образ храма, являющегося символом душевного успокоения, покаяния, духовного просветления лирического героя («Мой храм»). В интерпретации Ю. Балтрушайтиса лирический герой постигает тайный смысл бытия и обретает духовное счастье и успокоение «в безбрежности развернутых степей / где нет людской мятежности, / ни рынков / ни цепей» (Мой храм»). Степь становится тем священным местом, где, убежав от городской суеты, лирический герой совершает сакральный акт: читает благодарственную молитву «за чудо бытия». Храм становится неким участком земного и небесного пространства, о чем свидетельствует типологический ряд образов-символов: «степь», «горы», «вершины», «лазурная высь», «голубая бездна», которые работают на общую семантику преображения, очищения души, соединения души лирического героя с Тайной мирозданья. Ряд эпитетов: «светлый», «тайный», «синий» усиливает образное представление о сакральном значении храма. Как известно, синий в христианстве воспринимается как символ трансцендентного мира; светлый - цвет преображенного Христа (в фаворском свете или в момент воскресения); эпитет «тайный» сигнализирует о храме, скрытом от людских глаз, неизвестном многим.

Символика стихотворения включает многослойный потенциал значений, для прочтения которых могут быть использованы различные культурные коды. Так, например, в стихотворении «Мой храм» образ Бога представлен как в глубоком христианском сакральном смысле «Моя святыня вечная - / В безгранности морской, / Где воля бесконечная - / Над малостью людской» («Мой храм»), так и в рамках масонской мифологии. Как известно, в христианстве только Бог обладает бесконечным интеллектом и бесконечной волей, в их единстве составляющими саму сущность Бога. И с этим трудно не согласиться. Однако особого внимание заслуживает эпитет «морской», который неоднократно встречается в лирике Ю. Балтрушайтиса и который можно интерпретировать в рамках масонской символики. В поэзии Ю. Балтрушайтиса ярко представлены характерные для масонства образы странника-мореплавателя, который проходит шестую из семи, «возвещающей «всеобщее возрождение», ступеней «дороги света» (Мельгунов 2005, 16). Цель такого путешествия - «мистиче- 
ское соединение «внутреннего человека», стремящегося познать свет, c «внутренней церковью» - ключевой идеологемой масонства, понимаемой как царство Божие внутри человека» (Ильинская 2005, 80). Исходя из этого символика храма и эпитет «мой храм» прочитывается как постижение лирическим героем - странником Бога внутри себя: душа уподобляется храму.

Таким образом, в религиозно-поэтическом сознании Ю. Балтрушайтиса и А. Белого тема «духовного странничества» обрастает вариациями на тему. С одной стороны, все сборники поэтов-символистов представляют собой единый метатекст, в котором мотив странничества является доминантным. С другой, - лирическому герою отводится роль странника, жизнь которого в некоторых стихотворениях поэтов уподобляется морскому путешествию. Героев Ю. Балтрушайтиса и А. Белого привлекает не путешествие как таковое, а духовное странничество как религиозно-философская идея. Думается, данное исследование не дает возможности делать категоричные выводы. Требуется дальнейшее углубление в исследование проблемы. Однозначно можно говорить лишь о том, что мотив «духовного странничества», явно корреспондируя с мифопоэтическим контекстом, играет важную роль в поэтике А. Белого и Ю. Балтрушайтиса и непосредственно участвует в формировании уникальных художественных миров двух классиков литературы ХХ ст.

\section{Literat $\bar{u}$ ra}

Бахтин 1975 - М. Бахтин. Вопросы литературы и эстетики: исследования разных лет. - Москва: Художественная литература.

Белый 1994 - Андрей Белый. Критика. Эстетика. Теория символизма. В 2-х томах. Москва: Искусство. - (История эстетики в памятниках и документах). Т. 1.

Белый 1997 - Андрей Белый. Петербург: Роман. Стихотворения. - Москва: Эксмо. (Библиотека Всемирной Литературы).

Бердяев 1997 - Николай Александрович Бердяев. Судьба России. Самопознание. - Ростов на Дону. Издательство: Феникс.

Дунаев 2001-2003 - М. Дунаев. Православие и русская литература. В 6-ти частях. Москва: Христианская литература, 2001-2003, Ч. 5.

Ильинская 2005 - Н. Ильинская. Масонский код в русской поэтической традиции кризисных рубежей ХХ века. Південний архів. Філологічні науки: 36. наук. праць.Вип. ХХІХ. - Херсон: Вид-во ХДУ, 58-64. 
Исупов 2002 - К. Исупов. Путь в лабиринте. Кануны и рубежи. Типь пограничныхх эпох - типь пограничного сознания. В 2-х частях. Часть II. - Москва: ИМЛИ РАН, $431-443$.

Исупов 2001 - К. Исупов. Философия и литература «серебряного века» (сближения и перекрестки). Русская литература рубежа веков (1890-е начало 1920-х годов). Книга 1. - Москва: ИМЛИ РАН, «Наследие», 68-130.

Ключевский 1938 - В. Ключевский. Курс русской истории: переизд. Минск: Гизбел; Соц.-эконом. лит.

Лавров 2007 - А. Лавров. Андрей Бельй. Разысккания и этюды. Москва: Новое литературное обозрение.

Лау 2007 - Н. Лау. Мотив «духовного странничества» и образы «нищих духом» в художественных произведениях И. С. Шмелева. И. С. Шмелёв и литературно-эмиграционные процессы XX века. XIV Крымские международные Шмелевские чтения: Сборник материалов международной научной конференции (Алушта, 14-17 сентября 2005 года.). Симферополь: ООО «Форма», 288-300.

Лотман 1992 - Ю. М. Лотман. Избраннье статьи: в 3 m. Т. 2. Таллинн: Александра.

Масоны 2005 - Масоньl, история, идеология, тайньл и культ; под ред. С. П. Мельгунова и Н. П. Сидорова. Москва: Вече.

Медведева 2007 - Н. Медведева. Поэтическая метафизика И. Бродского и О. Седаковой в контексте культурной традиции: дис. ... д-ра филол. наук: 10.01.01. Ижевск.

Мержвинските 20014 - Б. Мержвинските. Символика пути в поэзии Юргиса Балтрушайтиса. Грани культурь Серебяного века: Сборник научньх статей / Литовский эдукологический университет. Филологический факультет. - Вильнюс : Издательство Литовского эдукологического университета, 199-213.

Минц 3. «Миф о пути» и эволюция писателей-символистов. [Электронный ресурс] 3. Минц. - Режим доступа: http://www.ruthenia.ru/mints/papers/mifoputi.htm

Моклецова 2014 - Ирина Васильевна Моклецова. Художественное творчество, публицистическая и просветительская деятельность А. Н. Муравьева в контексте русской литературы и культуры ХІХ века: диссертация ... доктора филологических наук: 10.01.01. Москва.

Тилкес-Заусская О. К. Четвертая Симфония Андрея Белого: точки «затемнения фокализации» и неомифологический порядок действия. [Электронный ресурс] / О. К. Тилкес-Заусская. - Режим доступа : http://cf.hum.uva.nl/narratology/_pdf/ tielkes.pdf. 


\section{Наталия Литовченко}

THE CONCEPT OF “SPIRITUAL PILGRIMAGE” IN THE LYRICS OF ANDREI BELY AND JURGIS BALTRUSHAITIS: TYPOLOGICAL ASPECT

Summary

The subject of research is the artistic expression of the concept "spiritual pilgrimage" in the cultural memory of the poetry of the early twentieth century. The article presents the transformation of a "spiritual pilgrimage" in the works of A. Bely and J. Baltrushaitis. On the basis of ideological and thematic "core" concept of "spiritual pilgrimage", revealed typological convergence, analyzed differences related with religious and poetic mind of the poet and author mythmaking. 